\title{
Professor Francisco Morato
}

Com a morte do Prof. Francisco Antonio de Almeida Morato, ocorrida nesta Capital aos 21 de maio de 1948, perdeu a Faculdade de Direito uma de suas figuras exponenciais. De fato, na personalidade dêsse mestre admirável se conjugavam harmoniosamente o coração e o espírito, cujos dotes invulgares lhe conferiam justo destaque, tanto no círculo das suas relações íntimas como nas lides profissionais e no cenário da vida pública.

A curiosidade intelectual do Prof. Francisco Morato, exercitada desde a juventude, mas nunca satisfeita, em. bora perscrutasse todos os setores do conhecimento humano e se detivesse de preferência nos domúnios do direito, deleitava-se de modo particular ante as formosuras do estilo. Tinha o mestre amoroso enlevo pela cultura clássica, pelos autores antigos da nossa língua, que frequentava assiduamente e cuja influência era manifesta em seus escritos e em sua oratória.

Como jurista, alinhou-se o Prof. Francisco Morato, no país, entre os maiores; como advogado, entre os mais diligentes e habeis. Professor nesta Faculdade, lecionava com assiduidade, zêlo e eficiência, expunha com elegância, era generoso e ameno no trato dos discípulos. Mantendo-se também, por muito tempo, na arena política, pôs a sua palavra, o seu prestígio, o seu saber a serviço dos princípios democráticos e do respeito à lei e à verdade eleitoral. Estas diretrizes lhe nortearam a atuação cívica, quer como parlamentar e chefe de partido, quer como um dos líderes da Revoluçǎo Constitucionalista de 1932, em que teve o ensejo 
de mostrar ao Brasil a sua pugnacidade e desprendimento na defesa da democracia.

Homem de sólido caráter, salientava-se ainda o Prof. Francisco Morato por uma integridade moral a tôda prova, figurando dest'arte, a justo título, como um dos excelsos valores do seu tempo.

Oito decênios profícuos, marcados por sucessivos lances de desassombro e dignidade, viveu êsse paulista ilustre. A Faculdade de Direito de São Paulo, da qual começou por ser aluno, passando mais tarde a professor catedrático, a diretor e, depois de aposentado, a professor emérito (o primeiro a receber do instituto essa distinção), rendeu-lhe, quando da sua morte, as mais altas demonstrações de estima. A Revista da Faculdade, por sua vez, neste número, que encerra a derradeira aula proferida pelo grande mestre, assinala a expressão da sua respeitosa homenagem à memória de quem por tantos anos ensinou à mocidade o direito, a honradez e o civismo. 


\section{Prof. Francisco Morato}

\section{(Notícia biográfica)}

o Dr. Francisco Antonio de Almeida Morato nasceu em Piracicaba, na província de São Paulo, em 17 de outubro de 1868, filho de Antonio Morato de Carvalho e de D. ambrosina de Almeida Morato.

Estudou humanidades no Colégio Moretzsohn e prestou os exames de preparatórios no Curso Anexo à Faculdade de Direito de São Paulo, na qual se matriculou em 1884, bacharelando-se em 30 de outubro de 1888.

Formado, abriu banca de advogado em Piracicaba, onde exerceu o cargo de promotor público, o de vereador, o de inspetor escolar, o de provedor da Santa Casa de Misericórdia.

Vindo para São Paulo, com grande renome de advogado e de jurista, entrou para o escritório do Dr. Estevam ne Almeida, do qual logo depois se separou, sem prejuizo da grande estima e admiração que reciprocamente os unia. Foi um dos fundadores do Instituto da Ordem dos Advogados de São Paulo e seu presidente de 1916 a 1922 e de 1925 a 1927.

Aprovado em concurso, foi nomeado professor substituto da setima secção da Faculdade de Direito de São Paulo, por decreto de 31 de outubro de 1917. Tomou posse em 13 de novembro, data em que recebeu o grau de doutor.

Por decreto de 13 de setembro de 1922, foi nomeado professor catedrático de prática do processo civil e comercial, tomando posse em 2 de outubro seguinte. 
Dotado de grande cultura juridica e literária, jurisconsulto e advogado, foi um dos fundadores do Partido Democrático, do qual tornou-se Presidente em sucessão ao Conselheiro Antonio Prado e pelo qual foi, em 1927, eleito deputado federal por São Paulo, revelando-se um dos nossos mais consagrados oradores parlamentares.

Foi o arbitro e delegado paulista que conseguiu resolver a secular questão de divisas de S. Paulo e Minas Gerais, assinando depois de dois anos de trabalho o Convênio de 28 de setembro de 1936; questão que atravessara insoluta o periodo de mais de dois séculos e que desafiara a sagacidade dos estadistas do Brasil Colônia, do Brasil Vice-Reinado, do Brasil Reino Unido, do Brasil Império e do Brasil República Velha.

Era membro do Instituto Histórico e Geográfico de $\mathbf{S}$. Paulo, Presidente do Tribunal de Ética Profissional, sócio do Automovel Club, do Jockey Club e do Club Comercial. Foi presidente do S. Paulo Club e um dos vice-presidentes da Liga Paulista contra a Tuberculose. Fez parte da Comissão Executiva das Novas Obras da Catedral. Tomou parte no Congresso Brasileiro de Direito Judiciário, onde orientou a memoravel campanha em prol do processo oral, vitoriosa na reforma da nova Lei Processual. Jubilado na cátedra de Direito Judiciário Civil, a Faculdade de Direito de S. Paulo conferiu-lhe o título de professor emérito, honra que pela primeira vez foi ali concedida. Jubilado, continua a prestar às letras jurídicas do País a contribuição de sua privilegiada inteligência, conforme se verificou com seu trabalho sobre Terras Devolutas, recentemente converído em lei pelo Estado de São Paulo. O Instituto da Ordem dos Advogados Brasileiros conferiu-lhe o título insigne de Membro Honorário, inscrevendo-o no respectivo quadro ao lado de Cilovis Bevilaqua, Lacerda de Almeida e dos poucos que têm recebido tamanha distinção. Em 1930 recusou, por coerência política, a presidência do Estado de S. Paulo. Recentemente, insistido, consentiu em servir por tres meses 
o cargo de Secretário da Justiça e Negócios do Interior de S. Paulo.

Além de inúmeros trabalhos forenses, pareceres, artigos de doutrina e temas de crítica, publicou quatro notaveis obras: "Da Carta Testemunhável", "Da Prescrição nas Ações Divisórias" (Obra considerada clássica), "Miscelânea Jurídica" e "As Divisas de São Paulo e Minas Gerais". São também inúmeros os seus discursos e conferências literários, jurídicos e históricos, esparsos pelas Revistas, Arquivos Judiciários e Magazines. 